\title{
기관절개술 후 발생한 기관무명동맥루
}

인제대학교 의과대학 상계백병원 이비인후과학교실

$$
\text { 조 경 래 }
$$

\section{A Case of Tracheo-Innominate Artery Fistula After Tracheostomy}

\author{
Kyoungrai Cho, MD \\ Department of Otolaryngology Head and Neck Surgery, Sanggye Paik Hospital, College of Medicine, \\ Inje University, Seoul, Korea
}

\begin{abstract}
- ABSTRACT -
Tracheo-innominate artery fistula is a rare, but it is most fatal complication after tracheostomy. Without proper management, the mortality is nearly $100 \%$ due to sudden massive tracheal hemorrhage. Early detection and urgent surgical management are essential for survival of patient. We present a patient who developed a tracheoinnominate artery fistula and survived as a consequence of proper management with literature reviews. ( $\mathbf{J}$ Clinical Otolaryngol 2008;19:247-250)
\end{abstract}

KEY WORDS : Tracheostomy $\cdot$ Complications $\cdot$ Innominate artery $\cdot$ Fistula.

\section{서 론}

기관절개술과 관련되어 발생하는 합병증 중 출혈은 술 중 출혈, 술 후 조기출혈, 술 후 지연출혈로 나뉜다. 술 중 출혈은 수술 중 대혈관에 직접 손상을 주어 발생하고 술 후 24시간 이내 발생하는 조기출혈은 부적절한 지혈이 나 혈액응고장애가 원인이 되며 수일에서 수개월에 걸쳐 발생하는 지연출혈은 기관연골염증, 기관절개구 육아조 직, 신생물 그리고 드물게 기관무명동맥루에 기인한다. ${ }^{1)}$ 기관무명동맥루의 발병율은 0.3 0.7\% 정도로 보고되고 있으나 즉각적인 수술적 치료가 행해지지 않으면 모든 환

논문접수일 : 2008년 8월 28일

논문수정일 : 2008년 9월 17일

심사완료일 : 2008년 10월 10일

교신저자 : 조경래, 139-707 서울 노원구 상계7동 인제대학교 의과대학 상계백병원 이비인후과학교실 전화 : (02) 950-1104 - 전송 : (02) 935-6220 E-mail : elysion20@hanmail.net
자가 사망하게 되므로 예방이 가장 중요하며 ${ }^{2)}$ 국내에서 는 흥부외과에서 수 회 보고 되었으나 이비인후과 문헌 에서는 보고된 바가 없으며 이비인후과 의사도 임상에서 경험할 수 있는 중요한 합병증이다. ${ }^{3,4}$

본 증례는 좌측 중대뇌동맥 동맥류에 의한 지주막하 출 혈이 발생하여 신경외과적 수술을 받은 65 세 여자환자 로 기관절개술 1 주 후 기관무명동맥루가 발생하였으나 적극적인 응급처치와 수술로 생명을 살릴 수 있었기에 문 헌고찰과 함께 보고 하는 바이다.

\section{증 례}

65세 여자환자가 의식소실을 주소로 응급실에 내원하 여 좌측 중대뇌동맥 동맥류에 의한 지주막하 출혈로 진 단 받은 뒤 신경외과에서 동맥류 결찰술을 시행받았다. 술 후 2 일째에도 혼미한 정신상태 계속되어 기관절개술 시 행하였으며 기관절개술 1 주 경과 후 기관 흡입 시 출혈을 주소로 이비인후과에 협진 의뢰되었다. 


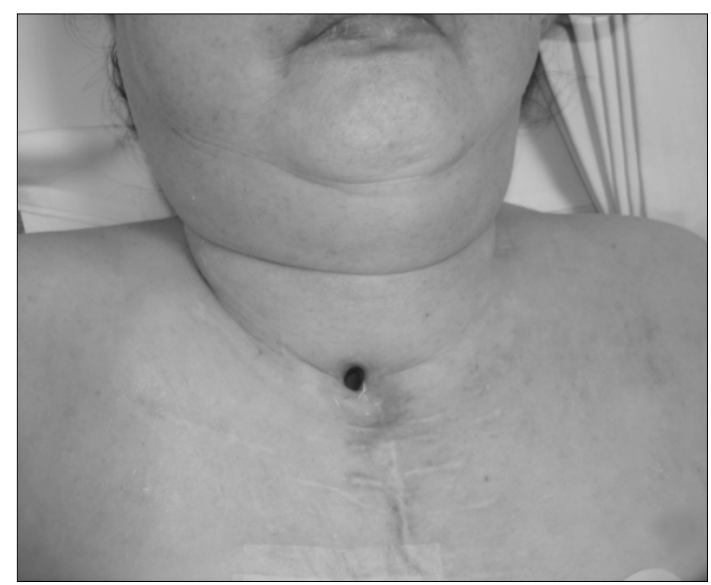

Fig. 1. Post operative 3 months finding. The tracheal stoma opening is made on the slightly right side of the tracheal midline. The opening is located between $4^{\text {th }}$ and $5^{\text {th }}$ tracheal cartilages, that is lower than usual level ( $3^{\text {rd }}$ tracheal cartilage).

기관절개구는 4 번과 5 번 기관연골 사이에 위치하였으 며 정중앙에서 $6 \mathrm{~mm}$ 정도 우측으로 벗어나 있었다(Fig. 1). $10 \mathrm{cc}$ 주사기를 사용하여 기관절개관 cuff 공기를 빼 고 관을 제거하는 순간 기관절개구로부터 다량의 출혈이 시작되었고 다시 기관절개관을 삽입하여 cuff 공기를 최 대한 팽창시켰으나 출혈이 지속되어 관을 제거하고 기관 흡입을 지속적으로 시행하면서 구강기관삽관튜브를 기관 절개창으로 깊게 삽입하고 cuff를 팽창시켰다. 튜브를 상 방으로 이동시키면서 지혈을 시도하여 출혈이 멈추었다. 기도를 확보한 뒤 흉부외과에 연락하였고 신속하게 응급 수술이 시행되었다. 정중흉골절개로 접근하여 관찰한 결 과 총경동맥과 쇄골하동맥이 분기되는 바로 아래에 무명 동맥 파열부가 관찰되었고 크기는 $1 \times 1.5 \mathrm{~cm}$ 이었다. 무명동맥 파열부의 상단과 하단을 절제한 뒤 직경 $12 \mathrm{~mm}$ 의 Hemashield vascular graft로 대체하였고 무명동맥 과 연결된 기관 결손부는 심외막으로 보강하였다(Fig. 2). 수술 1 주 뒤 정중흉골절개부에서 농이 관찰되고 혈액검 사상 백혈구증가 있어 창상 감염 의심 하에 재수술을 시 행하였다. 감염된 Hemashield vascular graft를 제거하 고 무명동맥의 상단과 하단을 절단 결찰하였다. 직경 8 $\mathrm{mm}$ 의 Ringed Gore-tex vascular graft를 이용하여 우 측 외장골동맥과 총경동맥, 액와동맥을 연결하여 혈액이 우회순환 되는 것을 확인하고 수술을 마쳤다. 수술 2년 경

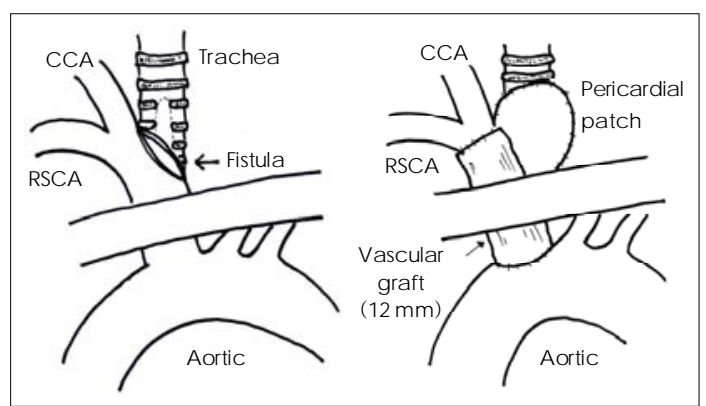

Fig. 2. Schematic drawings of pre and post operative finding. CCA : common ca rotid a rtery, RSCA : right subclavian artery.

과한 현재, 특별한 합병증 없이 환자 생존해 있다.

\section{고 찰}

기관무명동맥루에 관한 최초 보고는 1879년 Korte에 의해 기술되었고 기관절개술 후 기관 내 출혈로 사망한 5세 환아가 대상이었다. ${ }^{5)}$ 기관 무명동맥루는 기관절개 술 후 발생할 수 있는 가장 치명적인 합병증으로 수술적 치료가 행해져도 치사율이 $73 \%$ 에 이르므로 기관절개술 이 행해진 모든 환자에게 가능성을 염두에 두고 예방하 는 것이 가장 중요하다. ${ }^{6)}$ 기관무명동맥루는 기관절개술 중, 술 후 어느 때나 발생할 수 있으나 술 후 3 24일째 많이 발생하며 환자의 약 $65 \%$ 에서는 급성 대량출혈 양 상으로, 약 $35 \%$ 에서는 기관절개구로부터 소량의 출혈 이 선행되는 소견으로 나타난다. ${ }^{7)}$ 선행 증상으로 기관절 개관의 박동이 관찰되기도 하나 약 $5 \%$ 에 불과하므로 기 관절개술 후 48 시간 이후 기관절개구에 $10 \mathrm{~mL}$ 이상의 출혈이 있는 모든 환자에게는 가능성을 적극적으로 고려 해야 한다. 본 증례에서는 신경외과의 협진 요청을 받고 환자의 기관절개관을 제거하는 순간 급성 대량출혈이 발 생하였으며 $10 \mathrm{~mL}$ 이상의 선행 출혈이나 기관절개관의 박동성 움직임은 관찰되지 않았다.

합병증이 발생하는 기전은 기관절개관의 구조로 보아 3 부분으로 구분하는 데 첫째, 관의 오목한 몸체에 직접 손 상으로 제 3 기관륜 또는 그 이하에 시행된 낮은 위치의 기 관절개술, 비정상적으로 높게 위치하는 무명동맥, 경부의 과도한 신전이 원인이 된다. ${ }^{2}$ 무명동맥이 기관지를 통과 하는 높이는 대개 제 9 기관륜이나 제 6 기관륜에서 제 13 기 


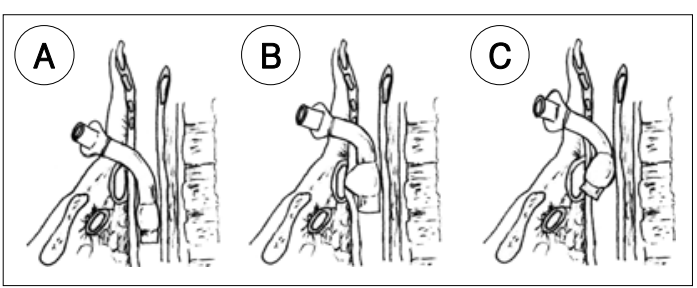

Fig. 3. Mechanisms of the tracheo-innominate artery fistula formation. A : Developed by the angle of a low lying tracheostomy tube. B: Developed by an overinflated tracheostomy cuff. C : Developed by the tip of a tracheostomy tube.

관륜까지 보고되고 있다. ${ }^{8)}$ 둘째는 기관절개관 cuff에 의 한 손상으로 무명동맥이 통과하는 제9기관륜에 cuff가 위 치하게 되어 cuff의 과도한 압력과 인공호흡기 사용기간 에 따라 발생 가능성이 증가하며 가장 흔한 기전으로 생 각되고 있다. ${ }^{2}$ 셋째, 기관절개관의 끝이 직접 자극하는 경우로 기관절개관의 부적절한 길이나 인공호흡기의 피 스톤 운동이 원인이 되며 저혈압, 스테로이드 사용, 패 혈증, 영양실조, 방사선 조사 기왕력 등이 악화요인이다 (Fig. 3). ${ }^{2)}$ 본 증례에서는 기관절개구가 제 4 번과 5번 기관륜에 위치하고 우측으로 $6 \mathrm{~mm}$ 정도 치우쳐 있었으 며 수술 중에는 단극성 전기 지혈기를 박리와 지혈에 사 용한 것으로 확인되었다. 낮은 기관절개와 전기 지혈기 의 과도한 사용이 합병증 발생에 영향을 미친 요인으로 생각되며 무명동맥의 비정상적인 높은 위치도 배제할 수 없다.

기관무명동맥루의 치료로 가장 중요한 것은 예방으로 기관절개구를 청결히 관리하며 적절한 습도를 유지시키 고 부드러운 기관흡입을 시행하는 것이 중요하다, 경부 의 과도한 신전을 삼가고 소아나 짧은 목을 가진 환자에 게 특별한 주의를 기울여야 한다. 적절한 크기의 기관절 개관을 선택하고 두부손상환자의 과도한 움직임을 예방 하는 것이 중요하며 무엇보다 인공호흡기를 조기에 이탈 시키도록 노력해야 한다. ${ }^{2)}$ 일단 합병증이 발생한 경우에 는 조기진단이 환자의 생명을 구하는데 필수적이다. 조 기진단을 위해 가장 중요한 것은 기관무명동맥루를 의 심하는 것이며 기관절개술 후 출혈이 있을 때는 기관지 내시경을 이용하여 기관 내를 자세히 관찰하여 출혈의 원인을 찾아야 한다. 출혈이 관찰되지 않더라도 박동성 의 괴사, 궤양부위는 즉각적인 수술의 적응증으로 고려
된다. ${ }^{9)}$ 기관으로부터 급성 대량 출혈이 발생되면 매우 위 험한 상황이므로 출혈을 막는 것이 중요하다. 사망의 원 인은 실혈에 의한 저혈량 속보다 기도폐쇄와 호흡부전이 므로 일차적으로 기관절개관의 cuff를 과팽창시켜 출혈 부위의 압박지혈을 시도한다. 출혈이 지속된다면 기관절 개관을 빨리 제거하고 구강삽관튜브로 경구 삽관을 시행 하여 출혈부위 아래에서 과팽창시켜 혈액의 흡인을 막 으면서 집게손가락을 넣어 기관 전벽을 흉골 후방으로 밀 어 압박하면서 지혈을 시도할 수 있다. 이러한 방법으로 90\% 이상의 환자들에서 출혈이 멈추었다고 보고되고 있 다. ${ }^{10,11)}$ 집게 손가락을 이용한 압박이 실패할 경우 구강 삽관튜브의 위치를 위아래로 조절하여 cuff를 과팽창시 키면서 지혈을 시도해야 하며 시도할 수 있는 마지막 방 법이므로 지속적으로 시도해야 한다. 출혈이 멈추게 되면 수술실로 이동하여 응급수술을 시행한다.

수술은 정중흉골절개술이 가장 선호되지만 종격동염과 흉골의 벌어짐을 피하기 위해 우측전방흉골절개술과 경 부절개를 사용하기도 한다. ${ }^{7}$ 기관무명동맥루의 근본적 인 해결은 루가 발생한 무명동맥의 상단과 하단을 절제 하고 양단을 결찰 하는 것으로 혈관손상부위를 직접 봉 합하거나 인조도관으로 대체하는 방법보다 높은 생존율 을 보인다. ${ }^{2}$ 무명동맥은 우측 상지와 우측 두경부에 혈 류를 공급하는 중요한 혈관이므로 이를 절단 봉합하면 뇌 허혈, 뇌졸증, 신경학적 증상 등을 유발할 수 있다고 알 려져 있으나 실제로 합병증이 발생하는 경우는 매우 드 물며 확실한 증거가 없다고 보고되고 있다. ${ }^{12)}$ 본 증례에 서는 무명동맥을 절단, 결찰 하지 않고 인조혈관으로 대 치하는 수술을 시행했고 1 주 뒤 창상감염으로 재수술 하 여 인조혈관을 제거하고 우측 외장골동맥과 총경동맥, 액 와동맥을 연결하는 우회수술을 실시하였다. 무명동맥을 절단, 결찰 하여도 특별한 합병증이 발생되지 않는다는 보고가 있지만 대뇌 혈류를 교차 공급하는 윌리스 환의 구조가 비정상인 환자에게는 치명적일 수 있으므로 이를 예방하려는 목적이었다.

기관무명동맥루는 드물지만 치명적인 합병증으로 예 방이 가장 중요한 치료이지만 일단 발생하게 되면 기도 확보를 위한 신속한 응급조치가 필수적이다. 평소 합병 증의 발생 가능성과 처치방법을 주지하고 있어야 응급상 황에서 환자의 생명을 살릴 수 있다. 
중심 단어 : 기관절개술 · 합병증 - 무명동맥 · 루.

\section{REFERENCES}

1) Mark CW, Marion EC. Tracheotomy and Intubation. In: Byron JB, Jonas TJ, editors. Head \& Neck Surgery-Otolaryngology, 4th ed. Philadelphia: Lippincott Williams \& Wilkins;2006. p.790-2.

2) Dyer RK, Fisher SR. Tracheal-innominate and tracheal esophageal fistula. In: Wolfe WG, editor. Complications in thoracic surgery. St Louis: Mosby Year Book;1992. p.294-301.

3) Cho SH, Cho SR, Kae YK, Kim JI. Tracheoplasty with using the Costal Cartilage, Including the perichondrium, for treating a tracheoinnominate artery fistula: surgical experience of one case. Korean J Thorac Cardiovasc Surg 2007;40 (9):651-4.

4) Kim MH, Kim IH, Kim KT, Kim HJ. Tracheoinnominate artery fistula: a case report. Korean J Thorac Cardiovasc Surg 1998;31 (5):536-9.

5) Korte W. Uber einige seltenere nachkrankheiten nach der tracheotomie wegen diphtheritis. Arch Klin Chir 1879;24: 238-64.
6) Wright CD. Management of tracheoinnominate artery fistula. Chest Surg Clin N Am 1996;6 (4):865-73.

7) Jones JW, Reynolds M, Hewitt RL, Drapanas T. Tracheoinnominate artery erosion: successful surgical management of a devastating complication. Ann Surg 1976;184:194-204.

8) Oshinsky AE, Rubin JS, Gwozdz CS. The anatomical basis for post-tracheotomy innominate artery rupture. Laryngoscope 1988;98 (10):1061-4.

9) Grant CA, Dempsey G, Harrison J, Jones T. Tracheo-innominate artery fistula after percutaneous tracheostomy: three case reports and a clinical review. Br J Anaesth 2006; 96 (1):127-31.

10) Utely JR, Singer MM, Roe BB, Fraser DG, Dedo HH. Definitive management of innominate artery hemorrhage complicating tracheostomy. JAMA 1972;220 (4):577-9.

11) Courcy PA, Rodriguez A, Garrat HE. Operative technique for repair of tracheoinnominate artery fistula. J Vasc Surg 1985;2 (2):332-4.

12) Brewster DC, Moncure AC, Daring RC. Ambrosino JJ, Abbott WM. Innominate artery lesions: problems encountered and lessons learned. J Vasc Surg 1985;2 (1):99-112. 